\section{Охотский Е.В.}

д-р социол. наук, профессор кафедры государственного управления и права Факультета государственного управления МГИМО МИД России, Москва e-mail: e.ohotskii@mail.ru

\section{Okhotsky E.V.}

Doctor of Social Sciences, Professor, Department of Public Administration and Law, International Institute of Administration, Moscow State Institute of International Relations (University) of Russia's Ministry of Foreign Affairs, Moscow

e-mail: e.ohotskii@mail.ru

\section{Государственный режим и стиль управленческой деятельности: трудности демократической трансформации}

\section{Аннотация}

В статье предпринята попытка проанализировать научную актуальность и практическую значимость для современной системы государственного управления проблематики режима правления и стиля управленческой деятельности, их форм и проявлений в практической деятельности. При этом исследуются базовые качественные характеристики и стилевые особенности функционирования аппарата государственного управления, трудности оптимизации служебной деятельности, проблемность и противоречивость преодоления коррупционно-бюрократических патологий, угроз, диссфункций и иных деформаций в практике государственного администрирования. Подчеркивается, что в определенный момент коррупционно-бюрократические механизмы превращаются в латентно-теневую систему управления, противостоять которой очень непросто. В результате сверху водворяются канцелярщина, коррупционный произвол, бездушие и безответственность, а внизу начинает господствовать правовой нигилизм, недоверие к властям, двойные стандарты.

Анализируя различенные виды стилей, автор специально останавливается на оптимально-эффективном стиле служебной деятельности, акцентирует внимание на его ценностных преимуществах и путях овладения, вводит в научный оборот понятие «стиль подлости и лицемерия» - стиль, основанный на лжи, двойных стандартах, фральсификациях, провокациях и коррупции.

В статье представлены некоторые оценочные суждения, сделаны соответствующие обобщения и выводы, анализируются меры, которые предпринимаются государством в плане наведения должного порядка в системе государственного управления и государственной службы. Сформулированы также предложения, которые, по мнению автора, помогут качественно реализовать те задачи, которые ставит государство в части демократизации управления и его инновационного обновления, борьбы с фрормализмом, бюрократическими злоупотреблениями, коррупцией, аппаратной замкнутостью.

\section{Ключевые слова:}

авторитаризм, государственное управление, бюрократизм, коррупция, демократия, нравственные основы служебных отношений, противодействие коррупции, профессионализм, рациональная бюрократия, режим правления, пути оптимизации стиля, стиль управления, стиль внесистемного управления.

\section{State Mode and Management Style: the Difficulties of Democratic Transformation}

\section{Abstract}

The article attempts to analyze the scientific relevance and practical relevance for the modern system of public administration mainstreaming mode of governance and management style, their forms and manifestations in practice. Thus explores the underlying quality characteristics and stylistic peculiarities of functioning of the state apparatus, the difficulty of optimizing performance, problematic and contradictory nature of overcoming corruption and bureaucratic pathologies, threats, dysfunctions and other deformations in the practice of public administration. It is emphasized that at some point the corrupt and bureaucratic mechanisms become latent shadow control system, which resist very difficult. In the result remain on top of the bureaucracy, the corruption, the brutality, the callousness and irresponsibility, and the bottom begins to dominate legal nihilism, distrust of authorities, double standards.

Analyzing the distinguished types of styles, the author stops at the optimally-effective style performance focuses on the value of the benefits and ways of learning, introduces into scientific circulation the concept of "style of meanness and hypocrisy" - style, based on lies, double standards, fraud, provocations and corruption.

This article presents some value judgments made appropriate generalizations and conclusions, analyzes the actions taken by a state in respect of establishing proper order in the system of public administration and public service. Formulated proposals which, in the opinion of the author, will help accurately implement the tasks put by the state in terms of democratic governance and innovation updates of the struggle against formalism, bureaucratic abuse, corruption, hardware isolation.

\section{Keywords:}

authoritarianism, governance, bureaucracy, corruption, democracy, moral foundations to official relations, anti-corruption, professionalism, rational bureaucracy, system of government, ways of optimization style, management style, style of the non-systemic control. 


\section{Режим государственного правления: типологическое разнообразие, особенности}

Последние годы вопросам политического режима и стиля государственно-управленческой деятельности уделяется недостаточно внимания. Причем не только в практическом отношении, но и в научном аспекте. Примерно такое отношение к указанной проблематике господствовало в советские времена. Лишь в годы перестройки и кардинальных рыночно-демократических трансформаций что-то начало меняться в конструктивную сторону. На какое-то время вопросы режима правления, стилевые аспекты и проблемы эффективности политикоуправленческой деятельности вышли даже на ведущие позиции научного поиска. В распоряжении специалистов появилось немало интересных работ, предметом которых стали теоретико-методологические проблемы рациональной бюрократии, бюрократизма и номенклатурности, политические, экономические, этические и социально-психологические условия эффективности государственной машины. Начали проводиться специальные исследования, в том числе докторского уровня. Свою стимулирующую роль сыграла резолюция XIX Bceсоюзной партийной конференции 1988 г. «О борьбе с бюрократизмом».

Отсутствие должного внимания со стороны ученых и политической общественности не означает, что проблема отсутствует. В том числе проблема демократии, демократизации правящего режима, овладения современным демократическим стилем управления. Наверное, неслучайно практически во всех президентских посланиях Федеральному Собранию РФ вопросы качества государственного менеджмента и его стилевые аспекты неизменно занимают ведущее место в кадровой проблематике. Так, в Послании на 2017 г. Президент счел необходимым еще раз обратить внимание на то, что управлять «на зыбкой почве слабого государства» и «безвольной власти» невозможно, на недопустимость формально-безразличного отношения к людям, призвал «не прятаться в служебных кабинетах, не бояться диалога с людьми», поддерживать их инициативу [16].

В процессе научного поиска предлагаются различные трактовки понятия «государственный режим» - важнейшей системной характеристики установленного в стране порядка. Й. Шумпетер, например, под режимом властно-государственного руководства понимал специфический тип институционального устройства, включая не только характер государ- ственного воздействия сверху, но и «обратную связь» посредством массового давления, выборов и контроля. Р. Даль в основу научной трактовки режима положил критерий конкурентности в борьбе за власть и степень вовлеченности граждан в управление делами государства. Отсюда несколько типов политических режимов: гегемонии с жестким ограничением прав и свобод граждан, запрещением оппозиции, отсутствием плюрализма; соревновательной олигархии, которая признает конкуренцию, но только на уровне правящей элиты; полиархии режима, находящегося ближе всего к демократическому идеалу. С. Хантингтон предложил свой подход, поделил режимы на военные, однопартийные, либеральные, квазидемократические и переходные, выделяя, соответственно, четыре типа недемократических режимов.

Классификацию режимов правления можно продолжать - критериев, подходов и оценок существует множество. Тем не менее в одном мнение подавляющего большинства исследователей совпадает: режим правления - это способ властвования, который определяет формы, методы, способы и стили, при помощи которых нормативные установления власти реализуются в практике государственных институтов. Одна и та же государственная система в зависимости от внутренних и внешних конкретноисторических обстоятельств способна успешно функционировать как в ординарных, так и неординарных условиях (кризисные, чрезвычайные, аномальные), как в условиях демократических, так и авторитарно-бюрократических и иных методов управления. Правда, обращают внимание на то, что по поводу нынешней демократии не должно быть иллюзий, что в той форме, к которой мы привыкли и которую мы знаем, во многом устарела, ведет к консервации властвующих элит, размыванию ее нравственных основ и ответственности.

Не теряют своей актуальности исследования таких видов властвования, как плутократия, этнократия, технократия, охлократия. Но чаще всего ученые сегодня говорят о двух типах государственных режимов: демократическом и антидемократическом - авторитарном, тоталитарном, военнополицейском, националистическом, фашистском и др. Критерий классификации - характер и качество власти, масштабность участия граждан в ее реализации.

В годы советского правления господствовал, как писалось в те времена, последовательно-демократический партийно-государственный режим, который непрерывно совершенствуется на основе единства теории и практики, всестороннего учета зако- 
номерностей общественного развития и накапливаемого опыта.

Считалось, такому режиму в принципе чужды формализм, догматизм и механистический подход к решению возникающих проблем [19, с. 163].

На самом деле все обстояло иначе. Господствовал стиль командно-административного управления с его номенклатурностью, господством партийногосударственного аппарата, централизацией, директивным планированием, отсутствием декларируемого разделения функций партийных, государственных и хозяйственных органов, жесткого контроля информационных потоков. Его крайняя форма - стиль большевистской принципиальности в духе сталинского деспотического режима.

В условиях демократического режима высшие органы власти имеют мандат народа. Власть реализуют в координатной системе разделения власти, политического и идеологического плюрализма, широкого общественного и территориального самоуправления. Государственное управление осуществляется методами права, убеждения, согласования, узаконенного нормативно-регламентационного, разрешительно-лицензионного и договорного регулирования. Принуждение носит правовой характер. Это форма правления высокого уровня «соответствия существу человека», обеспечивающая «абсолютную политическую равноценность индивидов» [4, с. 684-686]. Неслучайно К. Маркс демократическую форму организации государства считал важнейшим условием осознания человеком своих подлинных интересов. Хорошо понимал, что между истинно демократическими ценностями и ценностями буржуазно-либеральных концепций - расстояние огромного размера.

Понятно, что демократия в таком смысле - это идеал, к которому стремятся многие государства и страны. Между сущим и должным - дистанция большая и преодолеть ее непросто. Не исключение и современная Россия, которая в непростых условиях экономического кризиса, разгула русофобии и беспрецедентного внешнего санкционного давления пребывает в состоянии мучительного поиска модели своего будущего. Нельзя забывать и то, что не так-то просто преодолеть негативы недавнего исторического прошлого (в том числе периода диктатуры пролетариата и упрощенного понимания роли трудящихся в управлении) и бешенной антироссийской пропаганды и экономических дискриминаций современности. Поэтому важно, что в иерархии ценностей нынешнего российского государства на первое место поставлены человека и его достоинство. На высшем конституционном уровне закреплены принципы народовластия, демократии и законности. Государственные функции и должностные полномочия реализуются в соответствии с законом, а не по личному усмотрению или произволу [22, с. 77]. Разрешена деятельность оппозиционных политических сил. Гарантирована свобода слова, совести и печати, конфликты разрешаются не путем репрессий, а поиска консенсусных взаимоприемлемых решений. Государство исходит из того, что только в таких условиях люди могут спокойно, безопасно и свободно заниматься созидательным трудом, обустройством своей частной и общественной жизни [1, с. 182].

Именно на такой режим властвования и соответствующий ему стиль управленческой деятельности рассчитывали люди, поддерживая курс на перестройку и последующие кардинальные политические, экономические и социальные реформы. На ценности демократии и идеалы социально-справедливого общества ориентируются российские граждане и в современных непростых условиях. Понятно, что и здесь нужны новые, более действенные формы, которые обеспечивали бы максимальную открытость выборов, сменяемость элит, подотчетность должностных лиц, позволяли отзывать не оправдавших доверие граждан депутатов и губернаторов.

Говоря о режиме невозможно обойти стороной и ультра новаторские режимы правления, которые рождает современность. Образец - режим, господствующий ныне на Украине. Режим, сочетающий признаки охлократии, плутократии, майданной демократии, этноэгоизма и этнофобии, шантажа, популизма и демагогии, - хорошая среда для всякого рода фашиствующих правых секторов, экстремизма, системной коррупции, странных кадровых назначений и столь же странных увольнений, обращение к люмпенизированным слоям. И все это как на высшем элитном, так и низовом уровне управления. Везде проявляется социальная и идеологическая ненависть, чиновничье высокомерие и двойные стандарты, диктатура внеправовых сил. В конституции и уставах, декларациях и политических доктринах одно, а на самом деле иное.

Это уже не демократия, а ее пародия на грани диктатуры нравственной деградации. Это режим оккупационного администрирования в своей стране и по отношению к своему народу. Такой режим практически не реагирует ни на националистические беспорядки, ни на экономическую деградацию, ни на запредельность коррупции, ни на человеческие моральные и физические страдания. Для него такие «мелочи» - не помеха и куда меньшее зло, чем ан- 
типравительственные политические обличения, организованное патриотическое сопротивление, цивилизованное государственное строительство, тем более потеря благосклонности зарубежных покровителей. То, что общество органически не приемлет такую «демократию», власти мало волнует. Ответственность, высокая нравственность, забота об общественных интересах, готовность слышать других и уважать их мнение для такой власти - понятия из другого, чуждого ей мира. Понятно, что такой режим не может восприниматься спокойно и снисходительно. Самоустраниться от его «длинных рук» тоже не удастся. Его последствия печальны и трагичны.

Трудно поверить, но, похоже, в украинском обществе дают о себе знать факторы дестабилизации как далекого прошлого, так и недавних постсоветских времен - интриги периода боярско-княжеского правления, разновекторность и несовместимость интересов разных составляющих украинской феодальной знати в сложной конфигурации польских, русских, турецко-османских, шведско-литовских и иных внешнеполитических реалий, марионеточность во взаимоотношениях с иноземными королями и султанами, казацкая вольность, разгул петлюровщины, бандеровщины и национализма, неприятие коммунистического режима.

\section{Стиль управления - отражение господствующего режима властвования}

Государственный режим определяет стиль государственной управленческой деятельности, накладывает на него свой неизгладимый отпечаток, причем во всех звеньях и на всех уровнях властной иерархии. Хотя и здесь имеются нюансы. Если режим правления сфокусирован на политической стороне государственно-управленческой деятельности, то стиль характеризует «технологии» этой деятельности с точки зрения рациональности, эффективности, нравственности и имиджевой составляющей. В условиях демократического режима, например, не исключена возможность авторитарности и бюрократизма. В условиях тоталитарного правления рассчитывать на демократизм управления очень трудно. Стиль характеризует качественную определенность конкретного управляющего действия. Причем это не арифметический набор апробированных или новаторских приемов, форм и методов реализации властных полномочий. Это система, которая придает управленческой деятельности качественную определенность с точки зрения управленческой, правовой, организационной и нравственной культуры.
В реальной практике чаще всего проявляется три стиля: авторитарно-бюрократический, либеральнопопустительский и демократический. Используется также и другая классификация стилей: директивный (административно-бюрократический, авторитарный, административно-командный, деспотический), либеральный (либерально-попустительский, охлократический), демократический (коллегиальный, кооперативный). Одни из них системно присущи господствующему режиму, другие носят внесистемный характер.

Демократический - это стиль стимулирования самостоятельности и инициативы, ориентирован на гуманистические идеалы и разрушение бюрократических барьеров. В общении господствует коллективизм, вежливость, доброжелательность и доверие. Требователен, но справедлив. При таком стиле ставка делается на отношения взаимного уважения и эффективного контроля, в управленческой деятельности поощряется самовыражение, сотрудничество и деловитость, правдивость и тактичность. Руководитель предпочитает действовать методами убеждения, всячески поощряет инициативу, ориентирует подчиненных на высокопроизводительный, инициативный труд с полной самоотдачей. Именно демократический стиль соответствует требованиям нынешней российской действительности.

Жаль, что о доминировании демократического стиля в современной российской аппаратной практике говорит лишь 7,2\% экспертов. И это при условии, что в управлении появилось немало новаторского. Принятие, например, управленческих решений на основе конкурентного стратегического анализа, проектное планирование с выходом на приоритетные национальные проекты, административное судопроизводство, общественные палаты, регулярные управленческие тренинги, утверждение перечня общественно полезных услуг и критериев качества их оказания.

Либерально-попустительский - стиль фактического самоустранения и виртуозной безответственности, руководитель равнодушно относится к тому, где, что и как делают его подчиненные, он фактически не контролирует исполнение принятых решений. Такой стиль неслучайно называют аномальным. Встречается он нередко, о его возможности в современной России говорит практически каждый пятый российский эксперт [9, с. 16]. Его основа демагогия, бездумная вера в самостоятельность и ответственность человека, а на самом деле - безразличие по отношению к другим и личная безответственность. В режиме либерально-попуститель- 
ского стиля вопросы решаются как бы сами собой, полномочия реализуются в режиме авралов и шараханий, решения принимаются методом проб и ошибок. Отсюда потеря качества, срывы сроков реализации даже самых рутинных решений. Острых конфликтов в этом случае не избежать.

Авторитарно-бюрократический - стиль императивного управления посредством предписаний, директив, распоряжений и жесткого контроля. Совет с народом и общение с подчиненными уходит на задний план, приоритет отдается online-взаимодействию. В его основе - абсолютизация принципа единоначалия, практически полное отрицание коллегиальных методов принятия решений. Для него характерны жесткость управляющего действия, догматизм и стереотипность. Такой стиль существенно осложняет морально-психологическую атмосферу, подавляет инициативу, стимулирует желание выслужиться. Приемлем ли стиль такой иррациональной рациональности в условиях демократического правового государства? Ответ однозначен: конечно, нет!

Тем не менее бюрократический стиль, как и другие, носят системный характер, соответствуют в принципе господствующему политическому режиму, в большей или меньшей степени ориентированы на ценности декларируемые государством ценности. Куда неприятнее стиль внесистемного управляющего воздействия, который характерен для управления в условиях, например, фашиствующего режима с примесями махновщины и анархизма.

Такой стиль мы обозначим термином стиль подлости и лицемерия. Это стиль, который кардинально в негативную сторону отличается от стиля даже самого жесткого авторитарно-бюрократического управления с его консерватизмом, формализмом и корпоративной этикой. Его носители формально не нарушают закон, стараются не выходить за пределы сложившегося правового пространства, остаются в рамках установленных процедурно-процессуальных правил. Скорее, наоборот, используют эти правила в своих интересах и даже бюрократически злоупотребляют ими. Суть авторитарно-бюрократического стиля проявляется преимущественно в организационно-нравственном аспекте - номенклатурности, кастовости, господстве канцелярии и регламента, высокомерии по отношению к нижестоящему и раболепие перед начальством. Да еще виртуозном владении искусством переключения внимания на второстепенные вопросы и перекладывании проблем «с больной головы на здоровую».
Стиль же подлости и лицемерия, как мы его обозначили, отличается куда более жесткими и крайне опасными для общества негативами: цинизмом и практически полным отсутствием совести. Это стиль, осознанно основанный на лицемерии, двойных стандартах, социальной и идеологической нетерпимости. Обыденным становятся фальсификации, политические демарши и идеологические расправы, правовые фикции, националистические спекуляции, бандитское давление на суды, прокурорские органы и адвокатов, опора на экстремистские силовые формирования, противозаконный информационный диктат.

В чистом, сугубо «академическом виде» ни один из представленных стилей не существует. Чаще всего имеет место сочетание нескольких стилей при ведущей роли какого-либо одного из них. Поэтому определить уровень оптимальности стиля непросто. Однозначно лишь одно: без профессионализма, организованности, порядочности и авторитета субъектов управления трудно говорить об оптимальности стиля, нельзя рассчитывать на «эффективную профессиональную и морально-деловую среду» управленческого процесса.

В обобщенной форме основные черты оптимально-эффективного стиля служебной деятельности можно представить как: 1) умение сконцентрироваться на конструктивно-созидательной повседневной работе; 2) способность работать без призывов, напоминаний и понуканий; 3) непримиримость к проявлениям пустословия, волокиты, коррупции и бюрократизма; 4) способность оценивать людей не по словам, а по достигнутым результатам. Именно такой стиль - базовое условие успешности государства, залог поступательно-эволюционного развития общества с ощутимыми позитивными переменами каждый день.

\section{Трудности демократизации стиля}

государственно-управленческой деятельности

Формируется стиль не сам по себе и далеко не всегда определяется сугубо личностными качествами субъекта управляющего действия. Во многом он задается господствующим в стране режимом правления. Поэтому в разных исторических условиях стили разные, и ученые их соответствующим образом классифицируют. В условиях монархического правления господствовал стиль трансформации до самых низов черты самодержавной абсолютной власти, в советские времена - командно-административный стиль большевизма, тотального политического контроля и подавления инициативы. В такой обстановке овладеть демократическим стилем было 
практически невозможно. К тому же работники партийного, советского и комсомольского аппарата (впрочем, как и сейчас) имели отделенное представление о сущности и особенностях научного стиля управления. И это при условии, что о стиле руководства писалось и говорилось немало. Проводились научно-практические конференции, публиковалось немало переводных монографических исследований. Немалый общественный резонанс имели научнопублицистические произведения. Предметом особого внимания исследователей стали проблемы политического лидерства, государственной службы, карьеризма, коррупционно-корыстных проявлений в политико-административной практике. Аналогичная ситуация сохраняется до сих пор.

В отечественной традиции понятия «начальство» и «бюрократия» всегда воспринимались критично, обязательно с некоторым негативным акцентом. Причем не только в массовом сознании, но и на уровне серьезных научных исследований. Люди всегда отрицательно относились к «единовластию бюрократии», «канцелярщине» и «бюрократическому стилю», при которых человек, с его правами, свободами и проблемами, в лучшем случае воспринимался как средство, а в худшем - как помеха для укрепления государственного могущества [10].

K сожалению, нередко подобное наблюдается и сейчас, несмотря на то, что бюрократическое администрирование, коррупция и безответственность повсеместно и искренне осуждается. Меры, им противостоящие, предпринимаются немалые. Тем не менее даже призывы самых высоких государственных инстанций идти по пути «дебюрократизации» и минимизации административного вмешательства [14], работать так, чтобы «не дискредитировать государство» [11], кардинально менять принципы работы, добиваясь того, чтобы все, что заявлено, исполнялось без всяких оговорок, ссылок и ведомственных толкований [15] повисают, как говорится, в воздухе. Даже конкретные президентские поручения исполняются не более, чем на $60 \%$ [12, с. 2].

Что говорить об уровне деловитости низовых звеньев управленческой пирамиды. Как следствие переход к стилю ручного управления, стремление желаемое выдать за действительное, трудности с преодолением немалого числа факторов торможения - безответственности, заторможенности научно-технического обновления, дефицитности инвестиционных ресурсов, недостаточности конкуренции, изъянов делового климата.

Сколько раз россияне слышали, что кризис достиг своего нижнего предела, что страна входит в восстановительный период, что финансово-банков- ская система стабилизируется, что вот-вот начнется рост валового внутреннего продукта? Произносится великое множество слов о креативности, инициативе, инновациях. Количество такого рода реляций приобрело таких масштабов, что исполнить их не просто сложно, но и невозможно в принципе. Вот почему с таким трудом осваиваются современные управленческие технологии, не уступает свои позиции бюрократизм с его формализмом и волокитой. Не говоря уже об отсутствии системности контроля исполнения принятых решений. На это обращает внимание практически каждый второй $(46,2 \%)$ эксперт. Главным рычагом управления является не стимулирование позитивного поведения, а запреты, ограничения $(22,5 \%)$ и ужесточение санкционных мер воздействия $(43,1 \%)[9$, с. 16$]$.

Удивительна ли после этого критика системы государственного управления? Представляется, сегодня следует вернуться к основополагающим идеям веберовской рациональности, попытаться переосмыслить их в свете современных реалий и постараться поставить на службу государству.

Напомним основные положения веберовской рациональности:

1. Бюрократия - это не просто технический инструмент управления, а особый статусный социальный слой людей, занимающих престижно-привилегированное положение в обществе, имеющих свои корпоративные интересы, свои добродетели, свою честь и гордость.

2. Каждая должность в государственном аппарате обладает строго определенной сферой полномочий, даже смена политических лидеров на вершинах власти для чиновников не представляет проблемы. Главное, чтобы административный процесс выстраивался в соответствии с действующим законодательством.

3. Работа в государственном аппарате - основной род занятий служащего и основной источник его материального благосостояния.

4. Служба основывается на специализации чиновников в соответствии с их профессиональной квалификацией.

5. Управленческая деятельность расчленяется на элементарные простейшие операции, каждое ее звено обладает вполне конкретной компетенцией.

6. Организация строится по принципу рациональной иерархичности и строгой исполнительной дисциплины. Отсюда абсолютная уверенность в том, что все распоряжения руководителя будут своевременно доведены до исполнителя, но будут и безукоризненно выполнены в соответствии с установленными процессуальными правилами. 
7. Служебная деятельность регулируется «последовательной системой абстрактных правил», служащий подчинен жесткой дисциплине и перекрестному контролю. Наличие стандартов и соответствующих регламентов обеспечивает четкость управленческой деятельности. Все работники наделяются соответствующими полномочиями, заняты своим конкретным делом, несут персональную ответственность за порученный участок работы.

8. Отношения между сотрудниками аппарата строятся в духе «формальной безличности». Bce личное и эмоциональное изгоняется из служебных отношений - никаких симпатий и антипатий, никаких привилегий для одних и предвзятого ущемления интересов и унижения достоинства других [2, c. 473].

Теория рациональной бюрократии в свое время была вершиной классической системы государственного управления и ознаменовала наступление эпохи организационной власти. Сегодня идеи, принципы и технологии рациональной бюрократии приобретают новое смысловое наполнение и по-прежнему могут рассматриваться в качестве базисной основы современного стиля государственного управления.

Образец такого стиля задает глава государства. Его трудолюбие, выдержка, способность видеть сильные и слабые стороны соперника, гибкость тактического действия, остроумие, открытость, регулярное общением с журналистами, учеными и рядовыми гражданами - образец стилевого искусства. Причем стиль этот не патерналистский и далеко не вождистский, как бы это кому-то ни хотелось представить. Даже несмотря на высокий уровень консолидации власти в его руках. Если бы это было так, то элитное окружение, чиновничество и все граждане страны почувствовали бы это на себе немедленно. Хотя решительности и амбициозности ему тоже не занимать [8]. Наоборот, обладая огромным терпением и тактом, Президент стремится к формированию доброжелательной атмосферы деловитости, стремится разобраться в существе дела и действовать рациональным способом. Лишь в исключительных случаях пользуется инструментом выражения недоверия. В этом проявляются его силы, гибкость, готовность вступить в переговоры в расчете на понимание и последующие конструктивные действия.

Важно, чтобы лучшие стилевые качества президента стали характерными для как можно большего числа структур и должностных лиц государственной управленческой иерархии. Общество рассчитывает именно на это. Общество одобряет подавляющим большинством голосов (63\%, по данным
Левада-Центра) политику современного государственного руководства, высказывает свое согласие на пребывание В.В. Путина на посту Президента после 2018 г. [3, с. 3].

Стиль деловитости, ответственности и результативности должен стать достоянием российской национальной системы государственного и муниципального управления. Иначе от негативов (дисфункций, рисков и других управленческих патологий) ручного управления с его сверхцентрализацией, ограничениями инициативы, подменой подчиненных, минуя промежуточные и параллельные иерархические структуры, неизбежностью ошибок не избавиться. Не всегда же требуется экстренное антикризисное или антисанкционное управление. Эффективно управлять надо при любых обстоятельствах. В стабильных и кризисных условиях, в оперативном режиме и на дальних дистанциях стратегически устойчивого социально-экономического развития, в условиях, когда решения принимаются в системном режиме или точечно, по усмотрению.

В научной редакции овладение оптимально-эффективным стилем управления означает:

- овладение секретами современной профессиональной управленческой культуры, преодоление формализма, укрепление служебной дисциплины, повышение персональной ответственности;

- децентрализацию управления на основе принципов демократизма, законности, активизации инициативы нижестоящих структур вплоть до органов местного самоуправления;

- воспитание высокой правовой и нравственной культуры управленцев и на этой основе продвижение по пути дебюрократизации и антикоррупционного оздоровления аппарата;

- создание здорового микроклимата в коллективах, внедрение системы научной организации труда с учетом возможностей современных IT-технологий;

- совершенствование системы перекрестного внутриаппаратного анализа, государственного аудита и внешнего общественного контроля.

Серьезным шагом в направлении обновления стиля управленческой деятельности, будем надеяться, станет реализация Основных направлений развития государственной гражданской службы Российской Федерации на 2016-2018 гг. [17].

На приоритетные места в документе поставлены задачи совершенствования системы профессионального развития, создания единого информационнокоммуникационного пространства служебной деятельности, обеспечения большей эффективности кадрового резерва, введения дополнительных мер 
по борьбе с элитной коррупцией и обеспечивающих неотвратимость имущественной ответственности коррупционеров. В качестве первоочередных мер определено: 1) обновление стандартов нормирования численности структурных подразделений органов государственной власти; 2) создание единой информационно-коммуникационной системы управления кадровыми процессами, 3) разработка новой методики проведения конкурсов на замещение вакантных должностей; 4) осуществление мониторинга эффективности профилактики коррупционных правонарушений.

Ученые все чаще задумываются над вопросами «нового прочтения» демократии, эффективности выборности и подотчетности, качества судебных систем, дебюрократизации управленческих отношений; при этом они рекомендуют:

- создать более действенную систему взаимодействия государственных органов с институтами гражданского общества, прежде всего с народными фронтами, неправительственными некоммерческими организациями, комитетами по противодействию коррупции, независимыми средствами массовой информации;

- принять в статусе федерального закона «Этический кодекс государственного гражданского служащего», ввести институт присяги добросовестного служения Отечеству и Государству, больше внимания уделить вопросам злоупотреблений «административным ресурсом»;

- создать эффективную систему мотивации профессионально-должностного карьерного развития государственных служащих, ввести «эффективный служебный контракт», шире практиковать горизонтальные кадровые перемещения, продолжить процесс национализации элит;

- прекратить практику постоянных штатно-кадровых реформ, покончить с формализмом в проведении конкурсов, аттестаций и квалификационных мероприятий, ввести в действие более строгие критерии оценки профессиональных компетенций и культурно-нравственного потенциала служащих. Господствовать во власти должна не серость, а профессионализм, инициатива и порядочность;

- строже пресекать проявления волокиты и бумаготворчества в форме часто никем не читаемых программ, планов, докладов, отчетов и т.п.;

- ужесточить контроль проведения всевозможных совещаний, планерок и семинаров, дорогостоящих и малоэффективных форумов и саммитов, сократить до оптимального объема деловой туризм;
- разработать программу качественного обновления системы профессиональной подготовки, переподготовки и повышения квалификации кадров управления, ввести в систему внутриаппаратную профессиональную учебу, психологические тренинги, наставничество.

- продвигаться далее по пути борьбы с коррупцией, помня, что победить коррупционное зло можно только при условии, когда будут поддерживаться честные и добросовестные, когда каждый на своем месте будет занят делом, а не бюрократической его видимостью. Коррупция процветает лишь там и только тогда, когда дело подменяется бумагами, когда коррупцию можно прикрыть убедительными докладами, красивыми отчетами и актами проверок.

Там, где отсутствуют реальные трудовые результаты, процветают бюрократизм и его непременный спутник - коррупция. Только тот, кто болеет за дело и занят реальным делом, является искренним противником бумаг и заседаний. У него нет ни сил, ни времени на писанину, пустопорожние заседания и составление формальных отчетов. Не победив бюрократизм, мы не победим коррупцию, а значит, не создадим обстановку трудовой активности, инновационного поиска и обновления. В обстановке бюрократизма человек перестанет честно трудиться, качественно работать становится невыгодно и неинтересно. Легче подсчитывать то, что сделали другие, выгоднее имитировать бурную деятельность, своевременно докладывать о проделанной работе и получать за это серьезное вознаграждение. Только общество от этого мало что получает: на выходе остаются лишь папки, протоколы, акты и многостраничные отчеты.

Перечень предложений можно продолжить, он достаточно внушителен. В самом общем виде вывод может быть сформулирован следующим образом: демократический стиль управления - важнейшая составляющая высокоэффективного и высокоавторитетного государственного управления. Его база демократическое правовое государство с республиканской формой правления и соответствующим парламентаризмом и независимыми судами [18, с. 72], рациональная организация политического процесса и социально-политическое единство народа [21, c. 369], оптимальность соотношения свободы и принуждения [7, с. 64], подлинный социальный диалог самая эффективная технология управления, позволяющая не только согласовывать действия всех участников процесса, но и разделять ответственность за их результат [20, с. 132], единство профессионализма, ответственности, инициативности, готовно- 
сти пойти на оправданный риск в условиях неопределенности, способность наполнить процесс управления общественно значимым содержанием, отражающим объективные потребности, интересы, устремления и волю людей [5, с. 90; 6, с. 39].

В такой же степени справедливо обратное: демократический, научно обоснованный стиль управления - важнейшее условие утверждения идеалов демократического правового, а значит, социально справедливого государства. Основные направления оптимизации стиля - дебюрократизация и реши- тельное антикоррупционное очищение аппарата, его численная и структурная оптимизация, профессиональное развитие и повышение персональной ответственности каждого за качество исполнения служебных полномочий, прекращение расточительного материально-финансового обеспечения, забота на деле о рачительном расходовании государственных средств.

\section{Литература}

1. Атаманчук Г.В. Управление: философия, идеология, научное обеспечение [Текст]: монография / Г.В. Атаманчук. - М.: Academia, 2015. - 416 c.

2. Вебер М. Избранные произведения [Текст] / М. Вебер; пер. с нем.; под общ. ред. Ю.Н. Давыдова. - М.: Прогресс, 1990. - $808 \mathrm{c}$

3. Гармоненко Д. Доверие к президенту бывает разное [Текст] / Д. Гармоненко // Независимая газета. - 2016. -17 ноября. - С. 3.

4. Еллинек Г. Общее учение о государстве [Текст] / Г. Еллинек. - СПб.: Юридический центр Пресс, 2004. $752 \mathrm{c}$.

5. Косенко О.И. Становление социального государства в России: актуальные проблемы государственного управления и пути их решения [Текст]: монография / О.И. Косенко, Е.В. Охотский. - М.: АТиСО, 2010. -143 с.

6. Кравченко С.A. Риски в нелинейном глоболокальном социуме [Текст]: монография / С.А. Кравченко. - М.: Анкил, 2009. - 224 с.

7. Леони Б. Свобода и закон [Текст] / Б. Леони: пер. с англ. В. Кошкина; под ред. А. Куряева. - М.: ИРИСЭН, 2008. - 308 c.

8. Личностные стили ведущих мировых политических лидеров [Электронный ресурс] // URL: studme.org〉... stili_veduschih_mirovyh...liderov

9. Магомедов К. Организационная культура в России: содержание, состояние, влияние на управление [Текст] / К. Магомедов // Государственная служба. -2016 . - № 4. - C. 16.

10. Медведев Д.А. Послание Президента РФ Федеральному Собранию РФ от 5 ноября 2008 года.

11. Медведев Д.А. Послание Президента РФ Федеральному Собранию РФ от 30 ноября 2010 года.

12. О возможных реформах в правительстве. Принцип вертикального управления ограничивает любые структурные трансформации [Текст] // Независимая газета. 2016. - 18 марта. - С. 2.

13. Охотский E.B. Государственный служащий: статус, профессия, призвание [Текст]: учебно-методический комплекс / Е.В. Охотский. - М.: Экономика, 2011. $702 \mathrm{c}$.

14. Путин В.В. Послание Президента РФ Федеральному Собранию РФ от 4 апреля 2001 года.

\section{References}

1. Atamanchuk G.V. Upravlenie: filosofiya, ideologiya, nauchnoe obespechenie [Management: philosophy, ideology, scientific support]. Moscow, Academia Publ., 2015. 416 p.

2. Veber M. Izbrannye proizvedeniya [Selected Works]. Moscow, Progress Publ., 1990. 808 p.

3. Garmonenko D. Doverie k prezidentu byvaet raznoe [Confidence in the President is a different]. Nezavisimaya gazeta [Independent newspaper]. 2016, p. 3.

4. Ellinek G. Obshchee uchenie o gosudarstve [general theory of the state]. Vstupitel'naya stat'ya I.Yu. Kozlikhina [Introductory article IY Kozlihina]. St. Petersburg, Yuridicheskiy tsentr Press Publ., 2004. 752 p.

5. Kosenko O.I., Okhotskiy E.V. Stanovlenie sotsial'nogo gosudarstva $v$ Rossii: aktual'nye problemy gosudarstvennogo upravleniya $i$ puti ikh resheniya [Becoming a social state in Russia: actual problems of public administration and ways of their solution]. Moscow, ATiSO Publ., 2010. 143 p.

6. Kravchenko S.A. Riski v nelineynom globolokal'nom sotsiume [Risks in the nonlinear globolokalnom society]. Moscow, Ankil Publ., 2009. 224 p.

7. Leoni B. Svoboda i zakon [Freedom and Law]. Moscow, IRISEN Publ., 2008. 308 p.

8. Lichnostnye stili vedushchikh mirovykh politicheskikh liderov [Personality styles leading political leaders]. Available at: studme.org>...stili_veduschih_mirovyh...liderov

9. Magomedov K. Organizatsionnaya kul'tura v Rossii: soderzhanie, sostoyanie, vliyanie na upravlenie [Organizational culture in Russia: the content, status, influence on management]. Gosudarstvennaya sluzhba [Public service]. 2016, I. 4, p. 16.

10. Medvedev D.A. Poslanie Prezidenta RF Federal'nomu Sobraniyu RF ot 5 noyabrya 2008 goda [Message from the President of the Russian Federation to the Federal Assembly on November 5, 2008].

11. Medvedev D.A. Poslanie Prezidenta RF Federal'nomu Sobraniyu RF ot 30 noyabrya 2010 goda [Message from the President of the Russian Federation Federal Assembly of 30 November 2010].

12. O vozmozhnykh reformakh $\mathrm{v}$ pravitel'stve. Printsip vertikal'nogo upravleniya ogranichivaet lyubye strukturnye transformatsii [On the possible reforms in the government. vertical management principle of limiting any structural transformation]. Nezavisimaya gazeta [Independent newspaper]. 2016, p. 2. 
15. Путин В.В. Послание Президента РФ Федеральному Собранию РФ от 12 декабря 2013 года.

16. Путин В.В. Послание Президента РФ Федеральному Собранию РФ от 1 декабря 2016 года.

17. Указ Президента РФ от 11 августа 2016 г. № 403 «Об Основных направлениях развития государственной гражданской службы Российской Федерации на 20162018 годы».

18. Хессе К. Основы конституционного права ФРГ [Текст] / К. Хессе. - М.: Прогресc, 1981. - 386 с.

19. Черненко К.У. Вопросы работы партийного и государственного аппарата [Текст] / К.У. Черненко. - М.: Политиздат, 1980. - 398 с.

20. Шахрай C.M. О Конституции: Основной закон как инструмент правовых и социально-политических преобразований [Текст] / С.М. Шахрай. - М.: Наука, 2013. $-919 \mathrm{c}$.

21. Эбзеев Б. С. Человек, народ, государство в конституционном строе Российской Федерации [Текст]: монография / Б.С. Эбзеев. - М.: Юридическая литература, 2005. $-576 \mathrm{c}$.

22. Эбзеев Б.С. Личность и государство в России: взаимная ответственность и конституционные обязанности [Текст] / Б.С. Эбзеев. - М.: Норма, 2007. - 384 с.
13. Okhotskiy E.V. Gosudarstvennyy sluzhashchiy: status, professiya, prizvanie : Uchebno-metodicheskiy kompleks [Civil servant: status, profession, vocation: Educationalmethodical complex]. Moscow, Ekonomika Publ., 2011. $702 \mathrm{p}$.

14. Putin V.V. Poslanie Prezidenta RF Federal'nomu Sobraniyu $R F$ ot 4 aprelya 2001 goda [Message from the President of the Russian Federation Federal Assembly on April 4, 2001].

15. Putin V.V. Poslanie Prezidenta RF Federal'nomu Sobraniyu RF ot 12 dekabrya 2013 goda [Message from the President of the Russian Federation to the Federal Assembly on 12 December 2013].

16. Putin V.V. Poslanie Prezidenta RF Federal'nomu Sobraniyu RF ot 1 dekabrya 2016 goda [Message from the President of the Russian Federation Federal Assembly on December 1, 2016].

17. Ukaz Prezidenta RF ot 11 avgusta 2016 g. № 403 «Ob Osnovnykh napravleniyakh razvitiya gosudarstvennoy grazhdanskoy sluzhby Rossiyskoy Federatsii na 2016 - 2018 gody» [Presidential Decree of August 11, 2016 № 403 “On the main directions of development of the state civil service of the Russian Federation for 2016 - 2018”].

18. Khesse K. Osnovy konstitutsionnogo prava FRG [Germany Foundations of Constitutional law]. Moscow, Progress Publ., 1981. 386 p.

19. Chernenko K.U. Voprosy raboty partiynogo i gosudarstvennogo apparata [Questions work the party and state apparatus]. Moscow, Politizdat Publ., 1980. 398 p.

20. Shakhray S.M. O Konstitutsii : Osnovnoy zakon kak instrument pravovykh i sotsial'no-politicheskikh preobrazovaniy [On the Constitution, the Basic Law as a tool for legal and sociopolitical transformation]. Moscow, Nauka Publ., 2013.919 p.

21 Ebzeev B.S. Chelovek, narod, gosudarstvo v konstitutsionnom stroe Rossiyskoy Federatsii [Man, the people, the state in the constitutional order of the Russian Federation]. Moscow, Yuridicheskaya literature Publ., 2005. 576 p.

22. Ebzeev B.S. Lichnost' i gosudarstvo v Rossii: vzaimnaya otvetstvennost' i konstitutsionnye obyazannosti [Personality and state in Russia: mutual responsibility and constitutional duties]. Moscow, Norma Publ., 2007. 384 p. 